\title{
Participation, CoOperatives and Performance: An Analysis of Spanish \\ MANUFACTURING FirMS*
}

(JANUARY 2002)

José Alberto Bayo-Moriones

Departamento de Gestión de Empresas

Universidad Pública de Navarra

Campus de Arrosadía

31006 Pamplona (Spain)

Phone: 34948 169377/169400

Fax: 34948169404

Email: abayom@unavarra.es

\section{Pedro Javier Galilea-Salvatierra}

Departamento de Economía

Universidad Pública de Navarra

Campus de Arrosadía

31006 Pamplona (Spain)

Phone: 34948169845

Fax: 34948169721

Email: galilea@unavarra.es

Javier Merino-Díaz de Cerio

Departamento de Gestión de Empresas

Universidad Pública de Navarra

Campus de Arrosadía

31006 Pamplona (Spain)

Phone: 34948169383

Fax: 34948169404

Email: jmerino@unavarra.es

\footnotetext{
* We thank to José Enrique Galdón for very helpful comments and discussions. The authors would like to thank Fundación BBVA and Spanish Ministry of Education (PB 98-0550) for funding provided.
} 


\section{Participation, Cooperatives and Performance: An Analysis of Spanish}

\section{MANUfaCtURing Firms}

Abstract: This paper attempts to analyze the effects that shopfloor participation has on firm performance and examine if cooperatives show better results than capitalist firms. Moreover, it tries to study if the impact of participation on performance is different in cooperatives and capitalist firms. To fulfill these objectives information about 965 Spanish manufacturing plants with at least fifty employees is used. The results indicate that there are not significant differences in the performance of cooperatives and the rest of companies. Our findings also show that the introduction of participatory practices generates positive outcomes both for capitalist firms and cooperatives, without differences in the magnitude of the impact.

JEL code: M12, P13 


\section{INTRODUCTION}

The last decade has witnessed a marked increase in companies adopting new organizational practices aimed at promoting shopfloor participation (Osterman, 2000). These efforts to achieve greater employee involvement have been launched in two directions. Firstly, there has been an attempt to create a series of communication channels to permit the two-way flow of information between managers and employees. Meanwhile, there is a growing tendency to allow workers more participation and decisionmaking rights in their jobs, in a departure from the traditional organizational structure in which the worker's tasks were strictly defined and employees were merely required to follow the supervisor's instructions to the letter.

The growing diffusion of these practices, aimed at promoting shopfloor participation in firms, has been accompanied by keen academic interest in researching the various issues that this involves, particular attention being paid to whether or not these practices actually lead to an improvement in the firm's performance and competitive edge (e.g. Batt and Appelbaum, 1995; Fernie and Metcalf, 1995; Black and Lynch, 1997; Ichniowski et al., 1997; Cappelli and Neumark, 1999; Ichniowski and Shaw, 1999).

Another example of employee participation, though of a very different nature, is to be found in producer cooperatives. Here, unlike the situation in typical capitalist firms, the workers are the owners and therefore hold all the control and return rights. The fact that these two rights are vested in the workers creates the need for an incentive framework completely different from that usually found in capitalist firms, and this will presumably have its effect on worker behavior and firm performance. The study of the

effects of employees' whole ownership rights on firm performance has given rise to a 
wide range of theoretical and empirical literature (Bonin et al., 1993; Porter and Scully, 1987).

The results of both shopfloor participation and worker co-operatives have received enormous attention in the literature. Less interest, however, has been directed towards the analysis of possible differences between cooperatives and capitalist firms, in terms of the effects of shopfloor participation programs on workers' morale and organizational performance. Cooperative firms, in which workers own return rights and elect the board of directors, present an employment relationship scenario that clearly differs from that found in conventional firms. This could explain different levels of effectiveness in the adoption of practices aimed at promoting more direct participation of workers in their jobs.

This paper takes data from an initial sample of 965 Spanish manufacturing plants, to study the relationship between employee involvement, cooperatives and performance. The aim is to find the answers to three questions. An assessment will first of all be made of the results obtained when shopfloor participatory schemes are installed. Next, cooperatives will be analyzed to see if they achieve better performance measures than other types of companies. Finally, this investigation will attempt to ascertain whether the effectiveness of employee involvement practices varies according to whether they are introduced in a cooperative or a capitalist firm. Shopfloor participation in both these kinds of companies will be analyzed in order to detect any possible differences in outcome.

There are several features of this paper that need to be underlined. First, it must be emphasized that the range of establishments analyzed means that they do not belong to a narrow sector of industry with limited relevance to the economy of the country as a whole. This, together with the size of the sample used, allows a higher degree of 
generalization of the results and conclusions achieved. Secondly, to the knowledge of the authors, this is the first paper to take such a large sample to study the relationship between co-operatives, participation and performance in Spain. This enlarges the geographical area covered by the empirical evidence surrounding this issue. Thirdly, in analyzing the effects of participation, both measures of plant performance, in its various management aspects, and measures of the situation and behavior of workers will be considered. Fourthly, nine different practices are considered in order to assess the degree of effort being aimed at developing participatory arrangements in the firm. This number of practices is large enough to provide a more reliable picture of the importance attached by each firm to promoting employee participation.

This paper is organized as follows. The next section contains a brief review of the economic literature dealing with employee participation, cooperatives and performance. Following that, there will be a description of the details of the process used in the collection of the data used in the empirical analysis, then a definition of the variables employed and an explanation of the estimation methodology. The empirical results will then be presented, after which the paper will end with a discussion of the main conclusions that have been reached.

\section{THEORETICAL FRAMEWORK}

\section{Employee participation}

There are several reasons for believing that shopfloor participation can produce positive outcomes both for employees and the firm. One of the usual reasons put forward is that employees gain access to productivity enhancing information. It has long been recognized that information is not evenly spread throughout organizations and that employees possess private information from which management could benefit. 
Employees engaged in routine, day-to-day, tasks are usually in a better position to detect inefficiencies in operations that may affect productivity (Nalbantian, 1987). The information derived from such activity is potentially very valuable to the firm as an input to production. By improving the use of information and knowledge in organizations and turning decisionmaking rights over to those who possess this firsthand knowledge, it is possible to speed up action and increase efficiency.

From the point of view of motivation, it must be underlined that participation has a significant effect on job characteristics. In so far as participatory schemes alter such aspects of the job as variety and autonomy (Hackman and Oldham, 1980), they can be expected to bring about an improvement in the intrinsic motivation of workers. This would reduce the disutility of effort and would, as a consequence, improve job satisfaction, morale and performance. These positive effects of participation on employee satisfaction and performance would be accompanied by a better performance by the firm as a whole, as well as a reduction in absenteeism and labor conflicts.

Also with respect to raising motivation, it is argued that employee involvement is likely to promote greater trust between managers and employees and greater commitment and identification of workers with the firm (Fernie and Metcalf, 1995), thus aligning individual objectives with those of the organization as a whole (Levine and Tyson, 1990).

In spite of all the above-mentioned advantages, however, employee participation also presents some drawbacks. In so much as employee participation involves the handing over of decision rights from owners to workers, it gives rise to an agency relationship. This relationship has some unavoidable costs, due to the imperfection of motivational devices (Levine and Tyson, 1990). Employees may use the greater autonomy available to them to their own ends, by shirking in their job. The latest 
institutional economics literature suggests that these agency costs increase with the number of people taking part in the decisionmaking process (Williamson, 1975; Jensen and Meckling, 1979).

Although participation can improve intrinsic motivation among employees, it can also create a negative effect, since it may prove more demanding and stressful and, therefore, increase disutility in the job (Ben-Ner and Jones, 1995). It is also necessary to take into account the costs involved in implementing and running schemes aimed at providing mechanisms for employee participation (Ichniowski and Shaw, 1995).

It is immediately obvious, therefore, that participation is an extremely complex phenomenon, making it very difficult to establish an unambiguous hypothesis as to the sign and magnitude of its effects on firm performance and whether they will be statistically significant. It would seem that the size and sign of the relationship can not be determined from a theoretical perspective and that they ultimately pose an empirical question (Jones and Pliskin, 1991). A large number of empirical papers have analyzed the effects of participation ${ }^{1}$ without, of course, always reaching the same conclusions. Nevertheless, it can be stated that the effects of shopfloor participation have generally been found to be favorable, especially if the performance measures analyzed have to do with worker motivation.

\section{Co-operatives and their efficiency}

Producer cooperatives are labor-managed firms where the workers are the owners and participate on a democratic basis in the ultimate authority over the decisions of the company, including the right to delegate some or all decisions to managerial organs ${ }^{2}$.

\footnotetext{
${ }^{1}$ Examples of reviews of this literature are Miller and Monge (1986), Cotton et al. (1988), Levine and Tyson (1990), Wagner (1994) and Doucouliagos (1995).

2 This assumption does not necessarily mean egalitarianism in the distribution of workers' income, or direct-democracy in decision-making, or anti-specialisation within the workforce. It is this concept of cooperatives, with these specific features, that is most typically used in the literature (see Putterman, 1984).
} 
Cooperatives must be considered from the ownership perspective. There are two aspects involved in the ownership of an asset. The first of these has to do with the rights to control the asset, which implies the right to make decisions concerning its use; all decisions are determined by majority vote among worker-members, either directly or through an elected manager or board of directors. The second aspect relates to the return rights, that is, the rights to net earnings from the asset. The combination of these two rights is seen as a powerful incentive to promoting efficiency in the use of the firm's assets and in any investment decisions that must be made. Cooperatives are an example of this combination, but their distinctive feature is that control and return rights are held by the workers.

Most of the economic literature sustains that the reason for there being so few cooperatives in market economies is that they are inefficient (Porter and Scully, 1987). The traditional picture of cooperatives is one of small firms unable to survive in the long term in a capitalist environment because of a variety of problems, mainly of a managerial and financial nature. However, little theoretical consensus has been reached, and few attempts have been made to solve the problem through systematic empirical research.

There are some disadvantages associated with co-operatives. Their inefficiency -compared to other forms of business organization, mainly public corporations- arises from various factors. Employees generally have limited wealth and hence may have trouble in financing labor-managed firms by themselves, while adverse selection and moral hazard problems limit the ability of co-operatives to raise funds in the credit markets. As employees, co-operative members already have much at stake in the success of their firm; as owners, they also have to invest financially in the firm, which leaves them even further exposed to firm-specific risk. As a consequence, cooperatives 
will tend to take very conservative decisions and will try to diversify more than other firms might, with all the negative consequences that this has on profitability.

The existing numbers of producer co-operatives can be partly explained by the substantial tax subsidies to which they are eligible ${ }^{3}$. However, they are also sometimes established for other reasons, since they may enjoy substantial advantages over conventional firms owned by capital suppliers. Cooperatives are formed for a variety of reasons; some of them idealistic, such as the desire to establish a workplace where everyone can participate (so that no individual assumes the role of boss). A brief examination will now be made of the main advantages of cooperatives from the economic point of view.

The fact that a firm is a cooperative does not necessarily mean that it is managed by the workers. These have the decisionmaking rights and elect the co-operative board and managers. The managers need not necessarily be worker-owners; they may be outside professionals. The recruitment of professional staff usually compromises internal democracy and, as a consequence, problems may arise with involvement among worker-owners. In other words, agency problems between management and principals also exist in cooperatives.

However, it is often argued that this problem is less acute in worker-owned firms than in capitalist firms. Workers' wealth is more concentrated in a single firm than is the case with capitalist investors, who usually diversify their investments and have no special need to be informed about the management of the firm. Workers, on the other hand, have both the opportunity and the need to stay informed about the effectiveness of management.

\footnotetext{
${ }^{3}$ There is also an indirect way of avoiding taxes in the co-operatives. Worker-owned firms can reduce, or avoid, corporate income tax by raising wages and, simultaneously, reducing profits.
} 
Closely related to the agency costs between ownership and management, are the agency costs between ownership and workers. When team production is present, cooperatives must face the incentive problem of free-riding by team members. Teamwork means that it is difficult to observe and verify individual effort (Alchian and Demsetz, 1972). As a consequence, an incentive problem arises, since any team member can stint on effort without facing a proportionate reduction in income. However, when workers are the owners of the firm, and are therefore assigned the return rights, the problem is alleviated and some of these costs are internalized, with the result that productivity is enhanced. In producer cooperatives, where employees have control and return rights, productivity and performance are improved as a result of fewer labormanagement disputes and increased incentive towards effort and cooperation among employees, whose income and wealth is tied to company performance. There is general agreement among researchers in organizational behavior that, when workers are owners, individual motivation is clearly enhanced.

In addition to the incentive explanation just mentioned, there are other reasons why cooperatives may achieve a superior performance. Mutual monitoring is encouraged in co-operatives because they are owned by the workers. It is often argued that worker-owners are better than managers at monitoring workers. Mutual monitoring may be more efficient than a hierarchical supervision mechanism (Williamson, 1975). Co-workers are often better able than outsiders to devise cheaper or more accurate ways of observing effort (Putterman, 1984). Empirical proof that this mutual monitoring takes place is that worker-owned firms are often cited as characteristically using fewer supervisors than capitalist firms (Bonin et al., 1993).

Another advantage of cooperatives is to be found in human specific capital investments that would not be possible in conventionally owned firms (Williamson, 
1985). Moreover, in co-operatives the usual gaps in the spread of information between management and workers do not occur. These information gaps are frequently the cause of disputes in the regular bargaining process over employment conditions and it often happens that strikes and lock-outs can be traced back to them (Hansmann, 1990).

\section{Participation and cooperatives}

Some recent contributions to the literature suggest that the benefits to be gained from participation depend on other aspects of the employment relationship and on the context in which it takes place (Levine and Tyson, 1990). Undoubtedly, the characteristics of the relationship between employee and firm in a producer cooperative differ substantially from those found in a conventionally owned company. In cooperatives, employees have the ultimate right of control over the firm, while also owning the return rights. Therefore, the introduction of shopfloor participatory arrangements may produce a very different outcome in firms where workers have full ownership rights.

Although initially it seems reasonable to expect that there will be greater diffusion of shopfloor participatory practices among cooperatives, this is may not necessarily be the case. These are two aspects that, although potentially linked, are different in nature. Whereas the distinctive feature of cooperatives is employee ownership, with the political and return rights that this entails, shopfloor participation has to do with the day-to-day life of the worker at his job. It is quite possible in cooperatives for individuals as owners to have control and return rights, while, as workers, they perform their duties in narrowly defined jobs with no autonomy.

As already mentioned, one of the problems generated by the handing over of decision rights, which comes about as a result of participation, is that they may be used by workers for their own benefit and, as a result, work against the interests of the firm. 
This negative consequence of participation will be less acute in the case of cooperatives. Although the incentive to free-ride does not entirely disappear, it is not as strong.

Whereas cooperative workers, as owners of the firm, will suffer an indirect loss if they fail to behave as they ought, this is not the case among workers in conventional capitalist firms. Since inappropriate behavior reduces the firm's profits and value, the return on the individual's share in the ownership of the firm will also be reduced.

Moreover, fellow workers, being fellow owners, will be keener to devote some time to monitoring tasks. If a worker is found by his colleagues to be guilty of shirking, social sanctions may be applied. In cooperatives, workers are subject to peer pressure, which makes it more costly for them to abuse their assigned decision rights.

As far as empirical evidence is concerned, we must point to the conclusions reached in the review made by Doucouliagos (1995). This article shows that there is a positive correlation between some forms of worker participation and productivity. The most interesting point for the purposes of the present discussion is that this correlation is stronger in the case of labor-managed firms than among participatory capitalist firms.

\section{METHODOLOGY}

\section{The process of obtaining data}

The information used in this paper was obtained in the context of a wider research project focused on the analysis of the new systems of production and work organization in Spain.

The Spanish manufacturing industry constitutes the scope of our study. The concept of manufacturing industry is clearly defined in the National Classification of Economic Activity (NACE), which includes all the manufacturing industries (from code 
15 to code 37) with the exception of oil refining and the treatment of nuclear fuel (code 23).

Plant was chosen as the unit of analysis, because it is at this level where the policies analyzed in the paper are determined, and therefore where problems arise and where the results must be analyzed. Further, attention focuses on the plants that employ fifty or more workers. This limit has been used in other studies relating to the research area (see Osterman, 1994) and it serves to cover a wide spectrum of the population employed in Spanish manufacturing firms, what is more it simplifies the field work. With these criteria the population consists of 6013 establishments. 965 plants were surveyed, after the adoption of a stratified sampling procedure based on industry and size.

Primary data was obtained from a pre-tested questionnaire specifically designed to carry out the research project. The questions concerning human resource management refer to blue-collar workers. In order to get the information, personal interviews were made to a manager of the plant. After an initial contact process that required 3246 telephone calls, 965 valid interviews were undertaken.

\section{Describing the dependent variables}

The performance measures, the dependent variables, to be used are of two types. On the one hand, we have a series of operational performance measures, that is, results more closely related to the productive activity of the organizations. On the other hand, we also possess some results that relate more directly to human resources management. No analysis will be made of financial results, since these data are not available. It is true to say, however, that participatory practices will have a more direct impact on results in the operational and human resource management areas. This is because financial results 
are also subject to the effects of other variables outside the strict realm of industrial management.

As a measure of direct performance outcomes, we will take the degree of improvement over the three previous years on five indicators, linked to the basic objectives of any productive system, and therefore, of any firm (Corbett and Van Wassenhove, 1993). These indicators are: the percentage of productive hours over the total number of hours of direct labor; the percentage of faulty finished products; the percentage of defective products in process; the percentage of meeting agreed deadlines, and the time that elapses between receiving the materials and delivering the product to the customer (process lead-time). OPERATIONAL captures in how many of these indicators there have been improvements in comparison with three years before. Therefore OPERATIONAL is an ordinal variable that takes integer values between zero and five and is based in the subjective judgment of the respondents.

Results of a subjective nature are often used in research on organizations. The different objective manufacturing performances, which are measured in absolute terms, depend to a great extent on the technology and type of process found at the plant. It therefore becomes difficult to establish comparisons when the data is obtained from a group of heterogeneous plants. Some studies (Venkatraman and Ramanujan, 1986; Powell, 1995) have shown that there is a strong link between objective performance measures and the same performance measures evaluated subjectively. Moreover, Machin and Stewart (1990) and McNabb and Withfield (1998) point out that there is no consensus about the most appropriate performance measure and that all objective measures have shortcomings.

Three measures of results in the area of human resource management are used: the rate of absenteeism in the plant (ABSENTEEISM), an indicator of worker satisfaction 
measured on a scale of 0 to 10 (SATISFACTION) and a binary variable (STRIKE) indicating whether there were hours lost to strikes over the last year (value 1) or not (value 0).

\section{Describing the independent variables}

Core independent variables. The first of our independent variables tries to capture whether the firm is or not a producer cooperative. COOPERATIVE is a binary variable that indicates whether the plant belongs to a cooperative firm (equals 1) or to a capitalist firm (equals 0$)^{4}$.

In order to measure the extent to which firms encourage employee participation, we have created an index (PARTICIPATION) which indicates how many of the nine involvement practices taken into account are applied in the factory. Therefore, PARTICIPATION takes integer values between 0 and 9. The nine practices considered are the following ones: the autonomy of workers in planning and organizing tasks, their participation in designing the jobs for which they are employed, their collaboration in the training of new workers, the installation of autonomous work teams, organization of improvement groups, the use of suggestion systems, consultation of workers via surveys, the celebration of open-days and meetings to inform the workers.

Control variables. AUTOMATION aims to capture the degree of flexible automation in the plant. The questionnaire enquired after four technical features that we felt to be directly related to the degree of automation: namely, robots or programmable automatons, automatic materials storage and retrieval systems (AS/RSs), computer

\footnotetext{
${ }^{4}$ One specific note must be made at this point. There are two legal forms for cooperatives in Spain. The classical one, usually named "cooperativa", where decisions are taken on a one-member, one-vote basis. There is a second legal form for cooperatives named "sociedad laboral" (labour corporation); where membership is possible for capital and labor owners, members have different grades of control and return rights, but with the legal requirement that workers have the majority of control rights. Some of this second type of cooperatives are sometimes created as a consequence of employee buyouts of financially troubled facilities that might otherwise shut down. In spite of these differences, we will use the term cooperatives to refer to both types since economic problems are the same.
} 
integrated manufacturing (CIM) and computer networks for the processing of the plant's production data. By applying factor analysis to these four variables, a single factor is obtained with an eigenvalue greater than one, which accounts for just over $47 \%$ of the variance. The factor loadings on these variables are greater than 0.44 , while Cronbach's alpha is 0.6278 . AUTOMATION is defined as the average of the four variables mentioned.

Plant size (SIZE) is measured in terms of the number of workers employed at the plant (the logarithm of this number, for better fit). To account for the influence of the age of the plant a dummy variable was included. AGE has a value of zero if the plant was established in 1970 or before.

The level of competition being faced by the firm is captured by the variable COMPETITION. This assesses on a scale of one to five, the evolution of competition levels over the last three years in the sector in which the plant operates. A score of one on this scale indicates a large decrease, whereas a score of five represents a large increase.

Table 1 displays the mean, the standard deviation and the correlations of the variables in the study.

\section{Insert Table 1}

The correlation matrix immediately provides the first clues as to how the variables interrelate. The most relevant for the purposes of this study are as follows:

COOPERATIVE shows no statistically significant relationship with the remaining variables.

PARTICIPATION is positively related to AUTOMATION, SIZE and AGE, thereby indicating that participation tends to be more widely practiced in larger, more fully automated and newly established plants. 
PARTICIPATION has a positive and statistically significant relationship with two of the four performance measurements considered; i.e. operational performance and degree of job satisfaction among employees.

COMPETITION shows no significant linkage with any of the variables.

Operational performance displays a different pattern from that of human resource management performance measures (there are no significant links between them).

This is the initial picture that emerges from the correlation table. Relationships between variables will undergo more thorough examination after the multivariate analysis that is applied at a later stage of the study.

\section{Estimation methodology}

Four models are employed to estimate the influence of the explanatory variables on the four dependent variables (four performance measures) used.

i) OPERATIONAL $=\beta_{0}+\beta_{1}$ PARTICIPATION $+\beta_{2}$ COOPERATIVE $+\beta_{3}$ SIZE + $\beta_{4} \mathrm{AGE}+\beta_{5} \mathrm{AUTOMATION}+\beta_{6} \mathrm{COMPETITION}+$

\section{$\beta_{7}$ PARTICIPATIONxCOOPERATIVE}

To estimate this, an ordered logit model is selected, which is distinguished by the fact that the dependent variable is an ordered qualitative categorical variable. The decision to choose this approximation model as opposed to discriminant analysis or a standard regression model, is based on the greater robustness of this type of model in withstanding the violation of the assumption of normality (Maddala,1983).

ii) ABSENTEEISM $=\beta_{0}+\beta_{1}$ PARTICIPATION $+\beta_{2}$ COOPERATIVE $+\beta_{3}$ SIZE + $\beta_{4} \mathrm{AGE}+\beta_{5} \mathrm{AUTOMATION}+\beta_{6} \mathrm{COMPETITION}+$ $\beta_{7}$ PARTICIPATIONxCOOPERATIVE

In this case a multiple regression model is used for the estimation. 
iii) SATISFACTION $=\beta_{0}+\beta_{1}$ PARTICIPATION $+\beta_{2}$ COOPERATIVE $+\beta_{3}$ SIZE + $\beta_{4} \mathrm{AgE}+\beta_{5} \mathrm{AUTOMATION}+\beta_{6} \mathrm{COMPETITION}+$ $\beta_{7}$ PARTICIPATIONxCOOPERATIVE

As in the case of ABSENTEEISM, a multiple regression model is used.

iv) STRIKE $=\beta_{0}+\beta_{1}$ PARTICIPATION $+\beta_{2}$ COOPERATIVE $+\beta_{3}$ SIZE $+\beta_{4}$ AGE + $\beta_{5}$ AUTOMATION $+\beta_{6}$ COMPETITION $+\beta_{7}$ PARTICIPATIONxCOOPERATIVE

In this case, since the dependent variable is binary, a logit model is estimated.

\section{RESULTS}

Results from previous models are shown in tables 2, 3, 4 and 5. For each of the dependent variables three estimations were made; the first includes only the control variables (AUTOMATION, SIZE, AGE and COMPETITION); the second incorporates the independent core variables (PARTICIPATION and COOPERATIVE) and, finally, in the third estimation, these are further extended to include an interaction variable (PARTICIPATION x COOPERATIVE).

Table 2 summarizes the results of the estimation intended to explain improvement in operational performance. The first detail to emerge is the significant link between improvement and the extent to which participation is practiced $(\mathrm{p}<0.01)$. This appears to suggest that the effort made by Spanish manufacturing firms to increase involvement and acceptance of responsibility among their employees is rewarded with an improvement in performance in all production related activities. Other notable features are the negligible influence of whether or not the firm is a cooperative on performance improvements and the fact that the impact of participation on operational performance is no stronger in cooperatives than in any other type of firm (PARTICIPATION $x$ COOPERATIVE is not significant). 
As far as the remaining variables are concerned, it is worth mentioning that AUTOMATION and SIZE show a positive and statistically significant relationship with the majority of operational results, a feature that is common to all three models.

\section{Insert Table 2}

Table 3 summarizes the results obtained when the model is applied to absenteeism. Here it emerges that PARTICIPATION, COOPERATIVE and the interactive term plus all fail to be statistically significant. The rate of absenteeism remains unaffected by the adoption of participatory practices on the part of the firm and also fails to show any link with the fact that the employees may be owners of the firm.

It is worth underlining the fact that absenteeism increases with the size of the firm and is significantly higher in firms established prior to 1970 than in more recently created enterprises (post 1970). Neither the degree of automation nor the level of competition prove to be related to rates of absenteeism.

\section{Insert Table 3}

Table 4 summarizes the results obtained on the dependent variable SATISFACTION. These show that PARTICIPATION is associated in a positive and statistically significant manner $(\mathrm{p}<0.01)$ with the degree of job satisfaction among workers. In other words, in firms where participatory practices are more widely applied, workers show a higher level of satisfaction with their jobs.

On the other hand, neither COOPERATIVE on its own nor multiplied by PARTICIPATION appears to play a significant role in this model, which shows that job satisfaction among workers does not increase when they own the firm nor is the impact of participation on job satisfaction any greater among cooperative workers.

With respect to the impact of the remaining variables on SATISFACTION, it can be seen that both AUTOMATION $(\mathrm{p}<0.01)$ and SIZE $(\mathrm{p}<0.05)$ prove to be significant, 
albeit in opposite directions. Thus, in firms using more complex technology, there is a higher level of job satisfaction, which seems to suggest that workers feel happier as their jobs become more challenging, and less dreary and monotonous. However, the larger the firm, the less satisfied its workers appear to be with their jobs. This is possibly due to the fact that it is usually harder for workers to become identified with organizations of large dimensions.

As a final point, it emerges that neither the age of the plant nor the level of competition to which it is subjected are in any way associated with the degree of job satisfaction shown by workers.

\section{Insert Table 4}

Table 5 summarizes the results obtained on STRIKE, the last of the variables considered in the model. Here only one of the explanatory variables included, SIZE, proves to be statistically significant. These results indicate that the larger the firm, the more likely it is that hours will be lost due to strikes. The other control variables are not significant. Here the dependent variable is unaffected by either the extent of the participatory practices or whether or not it is a cooperative; the interaction of the two variables also fails to have any impact.

\section{Insert Table 5}

\section{CONCLUSIONS}

A broad literature has analysed the advantages and disadvantages of employee participation. There is also a vast literature investigating the efficiency of the cooperative business form, focusing mainly in their results compared to the capitalist conventional firm. 
Using information referred to an initial sample of 965 Spanish manufacturing plants, our paper looks at the relationship among shopfloor participation, cooperatives and performance. More specifically, we have analyzed the effect of this type of participation on performance; if cooperatives have results significantly different from the conventional capitalist firms, and if participation practices have different effects on firm performance depending on whether the firm is a cooperative or a capitalist firm. Performance measures considered in this paper are of two types. Firstly, we analyze results referred to the different aspects of the operational performance of the plant. Secondly, we examine variables related to motivation and workers behavior.

From the empirical estimations made, various results emerge. Firstly, we have found that the adoption of participation practices in the plant leads to a significant improvement in her operational results. Secondly, we must underline that cooperatives have no better or worse results than capitalist firms; being a cooperative per se does not make any difference. This conclusion is applied to all the performance measures considered. Thirdly, we have found that the effects of participatory arrangements do not differ between cooperatives and capitalist firms. Our results show that employee participation has positive outcomes in both types of firms.

Our results have several implications. The non-economic literature highlights the impact of participation in worker motivation. They argue that participation can improve workers intrinsic motivation and, as a consequence, it brings about a better individual and firm performance. However, our results discard this explanation. We do not observe that the adoption of participation practices is undoubtedfully associated with better worker behavior, and therefore a lower absenteeism rate or a smaller incidence of strikes. 
This makes us think that participation creates positive results for the firm are mainly related through a better use of information. Since participation implies an information transfer among the different hierarchical levels of the firm, decisions are taken more efficiently and better operational results are reached.

Some other implications can be obtained from the comparison of cooperatives and capitalist firm results. A possible explanation for the non-existence of significant differences in the case of cooperatives could be the balance of the advantages -mainly in terms of lower monitoring costs- and the disadvantages, that is, the non specialization of ownership and control and, as a consequence, some financing problems and more conservative decisions made by worker-owners. In addition to that, incentives coming from the cooperative ownership structure are diluted as the number of worker-owners increase, since the internalization of effort is reduced because of the free-rider effect and the lower incentives to monitor colleagues. Our sample considers cooperatives with more than fifty workers, so it excludes small cooperatives where the advantages mentioned are presumably stronger.

It is also usually argued that one of the advantages of cooperatives is the reduction, or even elimination, of the usual asymmetries of information between management and workers and, as a consequence, the number of conflicts as the case of strikes. Our study shows no differences in the incidence of strikes between cooperatives and capitalist firms when both adopt participation practices. Our explanation is that participation also promotes the diffusion of information and the reduction of the mentioned asymmetries. We can conclude that participation is more important than ownership structure for this informational goal. Participation makes both parts reveal strategic information so each other can know more clearly their bargaining positions and, a reduction of conflicts can be presumed. 
There are several limitations in our paper that should be noted. One is related to the characteristics of the performance measures used. It is true that subjective indicators allow us to analyze a larger number of aspects and questions and, at the same time, it makes possible to compare firms from very different manufacturing industries. However, we must recognize that an analysis based on objective data would have been complementary to the analyses made in this paper. A second limitation comes from the cross-sectional character of the information used, which logically can create some doubts about the unambiguity of causal relationships.

\section{REFERENCES}

Alchian, A.A., \& Demsetz, H. (1972). Production, information costs, and economic organization. American Economic Review 62(5), 777-795.

Batt, R., \& Appelbaum, E. (1995). Worker participation in diverse settings: Does the form affect the outcome, and if so, who benefits? British Journal of Industrial Relations, 33(3), 353-378.

Ben-Ner, A., \& Jones, D.C. (1995). Employee participation, ownership, and productivity: A theoretical framework, Industrial Relations, 34(4), 532-554.

Black, S., \& Lynch, L. (1997). How to compete: The impact of workplace practices and information technology on productivity. NBER Working Paper Series no. 6120, Cambridge, Massachusetts.

Bonin, J., Jones, D.C., \& Putterman, L. (1993). Theoretical and empirical studies of producer cooperatives: will ever the twain meet? Journal of Economic Literature 31(3), 1290-1320. 
Cappelli, P., \& Neumark, D. (1999). Do "high performance” work practices improve establishment-level outcomes? NBER Working Paper Series no. 7374, Cambridge, Massachusetts.

Corbett, C., \& van Wassenhove, L. (1993). Trade-offs? What trade-offs?. Competence and competitiveness in manufacturing strategy. California Management Review, 35(4) $107-122$.

Cotton, J.L., Vollrath, D., Frogatt, K., Lengnick-Hall, M., \& Jennings, K. (1988). Employee participation: Diverse forms and different outcomes. Academy of Management Review, 13(1), 8-22.

Doucouliagos, C. (1995). Worker participation and productivity in labor-managed and participatory capitalist firms: A meta-analysis. Industrial and Labor Relations Review, 49(1), 58-77.

Fernie, S., \& Metcalf, D. (1995). Participation, contingent pay, representation and workplace performance: Evidence from Great Britain. British Journal of Industrial Relations, 33(3), 379-415.

Hackman, J., \& Oldham, G.R. (1980). Work redesign. Reading, Massachusetts: Addison-Wesley.

Hansmann, H. (1990). The viability of worker ownership: an economic perspective on the political structure of the firm. In M. Aoki, B. Gustafsson, \& O. Williamson (Eds.), The Firm as a Nexus of Treaties (pp. 162-184). London: Sage Publications.

Ichniowski \& Shaw (1995). Old dogs and new tricks: determinants of the adoption of productivity-enhancing work practices. Brookings Papers on Economic Activity, special number, pp. 1-65. 
Ichniowski, C., \& Shaw, K. (1999). The effects of human resource management systems on economic performance: An international comparison of U.S. plants and Japanese plants. Management Science, 45(5), 704-721.

Ichniowski, C., Shaw, K., \& Prennushi, G. (1997). The effects of human resource management practices on productivity: a study of steel finishing lines. American Economic Review, 87(3), 291-313.

Jensen, M., \& Meckling, W. (1979). Rights and production functions: an application to labor-managed firms and co-determination. Journal of Business 52(4), 469-506.

Jones, D.C., \& Pliskin, J. (1991). The effects of worker participation, employee ownership, and profit-sharing on economic performance: A partial review. In R. Russell and V. Rus (Eds.), International Handbook of participations in organizations, vol. II: Ownership and participation (pp. 43-63). Oxford: Oxford University Press.

Levine, D.L., \& Tyson, L.D. (1990). Participation, productivity and the firm's environment. In A.S. Binder (Ed.), Paying for productivity, (pp. 183-243). Washington, D.C.: Brookings Institution.

Machin, S., \& Stewart, M.(1990). Unions and the financial performance of British private sector establishments. Journal of Applied Econometrics, 5, 327-350.

Maddala, G.S. (1983): Limited Dependent and Qualitative Variables in Econometrics. New York: Cambridge University Press.

McNabb, R., \& Whitfield, R. (1998). The impact of financial participation and employee participation in financial performance. Scottish Journal of Political Economy, 45(2), 171-187.

Miller, K.I., \& Monge, P.R. (1986). Participation, satisfaction, and productivity: A meta-analytic review. Academy of Management Journal, 29(4), 727-753. 
Nalbantian, H.R. (1987). Incentive compensation in perspective. In H.R. Nalbantian (Ed.), Incentives, cooperation and risk-sharing: Economic and psychological perspectives on employment contracts (pp. 3-43). Totowa, New Jersey: Rowman and Littlefield.

Osterman, P. (1994): How common is workplace transformation and who adopts it?. Industrial and Labor Relations Review, 47(2), 173-188.

Osterman, P. (2000). Work reorganization in an era of restructuring: Trends in diffusion and effects on employee welfare. Industrial and Labor Relations Review, 53(2), 179-196.

Porter, P., \& Scully, G. (1987). Economic efficiency in cooperatives. Journal of Law \& Economics, 30(October), 489-512.

Powell, T.C. (1995). Total Quality Management as competitive advantage: A review and empirical study. Strategic Management Journal, 16(1), 15-37.

Putterman, L. (1984). On some recent explanations of why capital hires labor. Economic Inquiry, 22(2), 171-187.

Venkatraman, N., \& Ramanujan, V. (1986). Measurement of business performance in strategy research: A comparison of approaches. Academy of Management Review, $11(4), 801-814$.

Wagner, J.A. (1994). Participation's effect on performance and satisfaction: A reconsideration on research evidence. Academy of Management Review, 19(2), 312-330.

Williamson, O (1975). Market and Hierarchies: Analysis and Antitrust Implications. New York: Free Press.

Williamson, O. (1985). The Economic Institutions of Capitalism. New York: Free Press. 
Table 1. Descriptive statistics and correlation matrix

\begin{tabular}{|c|c|c|c|c|c|c|c|c|c|c|c|}
\hline & Mean & s.d. & 1 & 2 & 3 & 4 & 5 & 6 & 7 & 8 & 9 \\
\hline 1. PARTICIPATION & 3.87 & 2.11 & & & & & & & & & \\
\hline 2. COOPERATIVE & 0.06 & 0.22 & 0.05 & & & & & & & & \\
\hline 3. AUTOMATION & 4.10 & 2.38 & $0.32 * * *$ & -0.01 & & & & & & & \\
\hline 4. SIZE & 4.93 & 0.89 & $0.14 * * *$ & 0.04 & $0.31 * * *$ & & & & & & \\
\hline 5. AGE & 0.48 & 0.50 & $0.07 * *$ & 0.02 & 0.01 & $-0.1 * * *$ & & & & & \\
\hline 6. COMPETITION & 3.54 & 0.89 & -0.02 & 0.03 & 0.01 & -0.03 & -0.01 & & & & \\
\hline 7. OPERATIONAL & 3.34 & 1.70 & $0.21 * * *$ & -0.03 & $0.21 * * *$ & $0.16 * * *$ & 0.02 & 0.03 & & & \\
\hline 8. ABSENTEEISM & 4.12 & 2.67 & 0.01 & 0.02 & 0.02 & $0.17 * * *$ & $-0.1 * * *$ & -0.01 & -0.03 & & \\
\hline 9. SATISFACTION & 6.86 & 1.50 & $0.21 * * *$ & 0.03 & $0.17 * * *$ & -0.03 & 0.05 & 0.04 & 0.05 & $-0.1 * * *$ & \\
\hline 10. STRIKE & 0.10 & 0.30 & 0.01 & -0.04 & 0.04 & $0.19 * * *$ & -0.01 & -0.02 & -0.01 & $0.14 * * *$ & $-0.1 * * *$ \\
\hline
\end{tabular}

$* * * \mathrm{p}<0.01,{ }^{* *} \mathrm{p}<0.05,{ }^{*} \mathrm{p}<0.10$ 
Table 2. Results of ordered logit model for OPERATIONAL $(n=670)$

\begin{tabular}{|c|c|c|c|c|c|c|}
\hline & Coef. & s.d. & Coef. & s.d. & Coef. & s.d. \\
\hline AUTOMATION & $0.145 * * *$ & 0.031 & $0.099 * * *$ & 0.033 & $0.099 * * *$ & 0.033 \\
\hline SIZE & $0.211 * *$ & 0.089 & $0.195^{* *}$ & 0.089 & $0.194 * *$ & 0.089 \\
\hline AGE & 0.027 & 0.141 & -0.018 & 0.142 & -0.014 & 0.142 \\
\hline COMPETITION & 0.073 & 0.078 & 0.082 & 0.078 & 0.080 & 0.078 \\
\hline PARTICIPATION & & & $0.158 * * *$ & 0.036 & $0.154 * * *$ & 0.037 \\
\hline COOPERATIVE & & & -0.370 & 0.324 & -0.803 & 0.805 \\
\hline $\begin{array}{l}\text { COOPERATIVE } \quad x \\
\text { PARTICIPATION }\end{array}$ & & & & & 0.100 & 0.174 \\
\hline Chi-squared & \multicolumn{2}{|c|}{$37.826 * * *$} & \multicolumn{2}{|c|}{$57.569 * * *$} & \multicolumn{2}{|c|}{$57.898 * * *$} \\
\hline $\log L$ & \multicolumn{2}{|c|}{-1077.058} & \multicolumn{2}{|c|}{-1070.653} & \multicolumn{2}{|c|}{-1070.486} \\
\hline Pseudo- $\mathbf{R}^{2}$ & \multicolumn{2}{|c|}{0.057} & \multicolumn{2}{|c|}{0.086} & \multicolumn{2}{|c|}{0.086} \\
\hline
\end{tabular}

$* * * \mathrm{p}<0.01,{ }^{* *} \mathrm{p}<0.05,{ }^{*} \mathrm{p}<0.10$ 
Table 3. Results of multiple regression model for ABSENTEEISM $(n=705)$

\begin{tabular}{|c|c|c|c|c|c|c|}
\hline & Coef. & s.d. & Coef. & s.d. & Coef. & s.d. \\
\hline CONSTANT & $2.169 * * *$ & 0.717 & 2.152 & 0.726 & $2.137 * * *$ & 0.728 \\
\hline AUTOMATION & -0.051 & 0.044 & -0.053 & 0.047 & -0.053 & 0.047 \\
\hline SIZE & $0.569 * * *$ & 0.121 & $0.568 * * *$ & 0.121 & $0.568 * * *$ & 0.121 \\
\hline AGE & $-0.65 * * *$ & 0.197 & $-0.65 * * *$ & 0.198 & $-0.66 * * *$ & 0.199 \\
\hline COMPETITION & -0.088 & 0.110 & -0.088 & 0.110 & -0.085 & 0.110 \\
\hline PARTICIPATION & & & 0.086 & 0.050 & 0.011 & 0.051 \\
\hline COOPERATIVE & & & -0.099 & 0.452 & 0.215 & 1.155 \\
\hline $\begin{array}{l}\text { COOPERATIVE } \quad x \\
\text { PARTICIPATION }\end{array}$ & & & & & -0.072 & 0.244 \\
\hline F (Fisher) & \multicolumn{2}{|c|}{$9.689 * * *$} & \multicolumn{2}{|c|}{$6.454 * * *$} & \multicolumn{2}{|c|}{$5.537 * * *$} \\
\hline $\mathbf{R}^{2}$ & \multicolumn{2}{|c|}{0.047} & \multicolumn{2}{|c|}{0.044} & \multicolumn{2}{|c|}{0.043} \\
\hline
\end{tabular}

$* * * \mathrm{p}<0.01,{ }^{* *} \mathrm{p}<0.05,{ }^{*} \mathrm{p}<0.10$ 
Table 4. Results of multiple regression model for SATISFACTION $(\mathrm{n}=777)$

\begin{tabular}{|c|c|c|c|c|c|c|}
\hline & Coef. & s.d. & Coef. & s.d. & Coef. & s.d. \\
\hline CONSTANT & $6.497 * * *$ & 0.385 & $6.250 * * *$ & 0.383 & $6.227 * * *$ & 0.384 \\
\hline AUTOMATION & $0.105 * * *$ & 0.024 & $0.069 * * *$ & 0.024 & $0.069 * * *$ & 0.024 \\
\hline SIZE & $-0.134 * *$ & 0.065 & $-0.154 * *$ & 0.064 & $-0.154 * *$ & 0.064 \\
\hline AGE & $0.186^{*}$ & 0.106 & 0.140 & 0.105 & 0.132 & 0.105 \\
\hline COMPETITION & 0.085 & 0.059 & 0.087 & 0.058 & 0.091 & 0.058 \\
\hline PARTICIPATION & & & $0.126^{* * *}$ & 0.026 & $0.130 * * *$ & 0.027 \\
\hline COOPERATIVE & & & & & 0.547 & 0.600 \\
\hline $\begin{array}{l}\text { COOPERATIVE } \quad x \\
\text { PARTICIPATION }\end{array}$ & & & & & -0.102 & 0.129 \\
\hline F (Fisher) & \multicolumn{2}{|c|}{$6.736^{* * *}$} & \multicolumn{2}{|c|}{$8.561 * * *$} & \multicolumn{2}{|c|}{$7.424 * * *$} \\
\hline $\mathbf{R}^{2}$ & \multicolumn{2}{|c|}{0.029} & \multicolumn{2}{|c|}{0.055} & \multicolumn{2}{|c|}{0.055} \\
\hline
\end{tabular}

$* * * \mathrm{p}<0.01,{ }^{* *} \mathrm{p}<0.05,{ }^{*} \mathrm{p}<0.10$ 
Table 5. Results of logit model for STRIKE $(n=776)$

\begin{tabular}{|c|c|c|c|c|c|c|}
\hline & Coef. & s.d. & Coef. & s.d. & Coef. & s.d. \\
\hline CONSTANT & $-5.23 * * *$ & 0.818 & $-5.19 * * *$ & 0.833 & $-5.18 * * *$ & 0.834 \\
\hline AUTOMATION & -0.021 & 0.055 & -0.017 & 0.057 & -0.016 & 0.057 \\
\hline SIZE & $0.687 * * *$ & 0.128 & $0.692 * * *$ & 0.129 & $0.694 * * *$ & 0.129 \\
\hline AGE & 0.182 & 0.244 & 0.201 & 0.246 & 0.212 & 0.247 \\
\hline COMPETITION & -0.122 & 0.132 & -0.119 & 0.133 & -0.123 & 0.133 \\
\hline PARTICIPATION & & & -0.013 & 0.062 & -0.020 & 0.062 \\
\hline COOPERATIVE & & & -1.532 & 1.028 & -5.292 & 4.751 \\
\hline $\begin{array}{l}\text { COOPERATIVE } \quad x \\
\text { PARTICIPATION }\end{array}$ & & & & & 0.737 & 0.787 \\
\hline Chi-squared & \multicolumn{2}{|c|}{$31.260 * * *$} & \multicolumn{2}{|c|}{$34.917 * * *$} & \multicolumn{2}{|c|}{$36.146 * * *$} \\
\hline $\log L$ & \multicolumn{2}{|c|}{-244.024} & \multicolumn{2}{|c|}{-242.194} & \multicolumn{2}{|c|}{-241.580} \\
\hline Pseudo- $^{2}$ & \multicolumn{2}{|c|}{0.081} & \multicolumn{2}{|c|}{0.090} & \multicolumn{2}{|c|}{0.093} \\
\hline
\end{tabular}

$* * * \mathrm{p}<0.01,{ }^{* *} \mathrm{p}<0.05,{ }^{*} \mathrm{p}<0.10$ 